\title{
IMPLIKASI YURIDIS FOTOKOPI SURAT KEPUTUSAN PENGANGKATAN PEGAWAI NEGERI SIPIL YANG DILEGALISASI SEBAGAI AGUNAN DALAM PERJANJIAN KREDIT BANK (STUDI DI PT BANK PERKREDITAN RAKYAT ASHI KABUPATEN BADUNG PROVINSI BALI)
}

\author{
Oleh: \\ Ida Bagus Gede Partha Suwirya ${ }^{1}$
}

\begin{abstract}
Writing this journal aims to analyze the credit agreement of the bank between the bank as a creditor with the Civil Servants as the debtor who uses a photocopy of the Decree of the Appointment of Civil Servants who are legalized as collateral. This journal is prepared using empirical juridical research method and the approach used is case approach and concept approach. Based on the results of this study it is known that the Bank piahk dare to receive a copy of the Decree of the Appointment of Civil Servants who are legalized as collateral in the credit agreement using the juridical basis of credit analysis $5 \mathrm{c}$ which is the basic principle of bank credit analysis based on the Law of the Republic of Indonesia Number 10 of 1998 on Amendment to Act Number 7 of 1992 Concerning Banking. Photocopy of a legalized appointment letter of civil servants belonging to movable and intangible objects that can be used as collateral based on the classification of legal guarantees because it has economic value in the form of slip of gajih civil servants. Trust to the debtor is the foundation of the bank providing credit funds.
\end{abstract}

\section{Keywords: Bank Credit Agreement, Photocopy of Certificate of Legalized Civil Servant Appointment, Collateral Credit, Trust}

\begin{abstract}
Abstrak
Penulisan jurnal ini bertujuan untuk menganalisis perjanjian kredit bank antara pihak bank selaku kreditor dengan pihak Pegawai Negeri Sipil selaku debitor yang menggunakan fotokopi Surat Keputusan Pengangkatan Pegawai Negeri Sipil yang dilegalisasi sebagai agunan. Jurnal ini disusun dengan menggunakan metode penelitian yuridis empiris dan pendekatan yang digunakan adalah pendekatan kasus dan pendekatan konsep. Berdasarkan hasil penelitian ini diketahui bahwa piahk Bank berani menerima fotokopi Surat Keputusan Pengangkatan Pegawai Negeri Sipil yang dilegalisasi sebagai agunan dalam perjanjian kredit dengan menggunakan dasar yuridis yaitu analisis kredit 5c yang merupakan prinsip dasar analisis kredit bank berdasarkan Undang-Undang Republik Indonesia Nomor 10 tahun 1998 tentang Perubahan Atas Undang-Undang Nomor 7 tahun 1992 Tentang Perbankan. Fotokopi Surat Keputusan Pengangkatan Pegawai Negeri Sipil yang dilegalisasi termasuk ke dalam benda bergerak dan tidak

1 Program Studi Magister (S2) Kenotariatan Universitas Brawijaya, Malang, Jawa Timur, Email: guspar60@yahoo.co.id
\end{abstract}


berwujud yang dapat dijadikan agunan berdasarkan klasifikasi hukum jaminan karena memiliki nilai ekonomis berupa petikan slip gajih pegawai negeri sipil. Kepercayaan kepada debitor merupakan dasar pihak bank memberikan dana kredit.

\section{Kata kunci: Perjanjian Kredit Bank, Fotokopi Surat Keputusan Pengangkatan Pegawai Negeri Sipil yang dilegalisasi, Agunan Kredit, Kepercayaan.}

\section{PENDAHULUAN}

Berdasarkan Pasal

1313

KUHPerdata dinyatakan bahwa suatu perjanjian atau persetujuan adalah perbuatan dengan mana satu orang atau lebih mengikatkan dirinya terhadap satu orang lain atau lebih. Hubungan antara dua orang tersebut adalah suatu hubungan hukum dimana hak dan kewajiban diantara para pihak tersebut dijamin oleh hukum. ${ }^{2}$

Dalam Pasal 1 angka 2 UndangUndang Republik Indonesia Nomor 10 Tahun 1998 tentang Perubahan Atas Undang-Undang Nomor 7 Tahun 1992 Tentang Perbankan ${ }^{3}$ (selanjutnya disebut UU Perbankan), Bank adalah badan usaha yang menghimpun dana dari masyarakat dalam bentuk simpanan dan menyalurkannya kepada masyarakat dalam bentuk kredit dan atau bentuk-bentuk lainnya dalam rangkameningkatkantarafhidup rakyat banyak. Sedangkan yang dimaksud dengan Kredit dalam Pasal 1 angka 11 UU Perbankan yaitu penyediaan uang atau tagihan yang dapat dipersamakan

2 H.R. Daeng Naja, Hukum Kredit dan Bank Garansi,(Bandung: PT. Citra AdityaBakti, 2005), hlm. 175.

3 Lembaran Negara Republik Indonesia Tahun 1998 Nomor 182, Tambahan Lembaran Negara Republik Indonesia Nomor 3790. dengan itu, berdasarkan persetujuan atau kesepakatan pinjam meminjam antara Bank dengan pihak lain yang mewajibkan pihak peminjam untuk melunasi hutangnya setelah jangka waktu tertentu dengan pemberian bunga.

Proses pemberian kredit tentunya memiliki dasar dari aspek hukum. Pemberian kredit akan membentuk suatu hubungan hukum dengan segala akibat hukum yang dapat menimbulkan kerugian bagi Bank selaku kreditor apabila hal-halang mendasar dalam perjanjian kredit terlupakan. Hal-hal mendasar yang harus diperhatikan oleh pihak Bank dalam pemberian kredit salah satunya berupa adanya jaminan dari debitor yang dapat memberikan suatu keyakinan kepada Bank atas kesanggupan debitor untuk melunasi kredit sesuai dengan perjanjian. Keabsahan dan kebenaran subjek hukum dan objek hukum merupakan syarat utama dalam perjanjian. Keabsahan dan kebenaran tersebut didapat melalui proses meneliti dan analisis dari pihak bank. Data yang diteliti oleh pihak Bank merupakan data-data dari pihak debitor yang menyangkut mengenai identitas, 
karakter, pendapatan, jaminan dan kemampuan debitor dalam pemenuhannya guna pengembalian kredit berdasarkan perjanjian kredit.

Kredit yang memiliki arti kepercayaan jika dalam perspektif hukum dapat berarti:

1. Bahwa pemberian kredit oleh Bank kepada nasabahnya yang terlebih dahulu dibuatkan suatu perjanjian (hukum perjanjian) tidaklah berarti Bank tidak percaya kepada nasabahnya, tetapi perjanjian (kredit) tersebut sengaja dibuat sebagai suatu alat bukti (hukum pembuktian) bagi para pihak apabila terjadi perselisihan di kemudian hari.

2. Bahwa perjanjian kredit yang dibuat antara Bank dan nasabahnya adalah sarana untuk menuangkan segala macam jenis kesepakatan dan persyaratan kredit yang ada, termasuk cara-cara pembayaran bagi nasabahnya dalam melaksanakan prestasinya. $^{4}$

Dalam pemberian kredit ini tentunya melalui prosedur dan pemenuhan syarat-syarat tertentu dari pihak bank, salah satunya dengan perjanjian kredit yang disertai dengan agunan atau jaminan kredit. Tentunya jaminan kredit atau agunan tersebut dapat dipindahtangankan dalam hal ini memiliki nilai ekonomis yang berarti bahwa agunan tersebut memiliki hak yang dapat dialihkan

$4 \quad$ Op.cit, hlm. 22. hak kepemilikannya. Jaminan kredit atau agunan yang dijadikan salah satu persyaratan dalam pemberian pinjaman/kredit, menurut hukum digolongkan sebagai barang tidak bergerak dan barang bergerak serta berwujud dan tidak berwujud. ${ }^{5}$

Dalam Pasal 1 angka $23 \mathrm{UU}$ Perbankan menyatakan, agunan adalah adalah jaminan tambahan yang diserahkan Nasabah dan/atau Debitor kepada bank dalam rangka pemberian fasilitas kredit atau pembiayaan berdasarkan Prinsip Syariah. Agunan berupa surat-surat berharga yang salah satunya adalah Surat Keputusan Pengangkatan Pegawai Negeri Sipil (selanjutnya disebut SK Pengangkatan PNS) bukan merupakan benda yang dapat dipindahtangankan (hak kepemilikan dalam benda tersebut tidak dapat dialihkan), namun dalam praktek perbankan yang melihat dari nilai ekonomis pada SK Pengangkatan PNS tersebut menjadikannya dapat diterima oleh beberapa bank sebagai agunan. Terdapat pertentangan atas penggunaan SK Pengangkatan PNS sebagai agunan karena SK Pengangkatan PNS tersebut tidak dapat dialihkan sehingga akan menimbulkan kesulitan bagi pihak bank dalam melakukan eksekusi apabila terjadi kredit macet dalam pelunasan kredit yang dimaksud.

Pihak Bank juga harus berhatihati dalam pemberian kredit untuk mengurangi resiko yang akan 5 Hermansyah, Hukum Perbankan Nasional Indonesia,(Jakarta: Kencana, 2005), hlm. 68. 
timbul. Agunan dalam pemberian kredit memiliki arti keyakinan atas kemampuan dan kesanggupan debitor untuk melunasi hutangnya merupakan faktor yang penting untuk mengurangi resiko tersebut. Meskipun pemberian kredit tersebut berdasarkan kepercayaan, kegunaan agunan dalam perjanjian kredit sangat penting. Hal ini disebabkan apabila debitor tidak mampu membayar atau melunasi hutangnya, maka agunan ini yang akan digunakan oleh pihak Bank atau kreditor sebagai sumber pendanaan untuk melunasi kredit dari debitor itu sendiri.

Guna meningkatkan pendapatan dari Bank, banyak kebijakan-kebijakan dikeluarkanolehpihakBank.Kebijakan yang dijalankan oleh salah satu pihak Bank yang berada di Bali yaitu dengan menggunakan SK Pengangkatan PNS. PT. Bank Pembangunan Daerah Bali (selanjutnya disebut PT. BPD Bali) telah menjalankan kebijakan dengan mengeluarkan dananya dalam bentuk kredit yang menggunakan SK Pengangkatan PNS yang berada di daerah, kota, maupun kabupaten di Bali sebagai agunan. Melihat hal tersebut, dapat dipertanyakan bahwa bagaimana implikasi yuridis dalam penggunaan SK Pengangkatan PNS sebagai agunan kredit.

Ketatnya persaingan usaha dibidang perbankan yang khususnya di Bali telah membuat masing-masing bank mengeluarkan berbagi kebijakan dalam penyaluran dana kredit. Adanya persaingan kredit yang ketat tersebut membuatsalahsatuBankmengeluarkan kebijakan dengan memperbolehkan debitor menggunakan fotokopi SK Pengangkatan PNS yang dilegalisasi. Hal tersebut terjadi karena SK Pengangkatan PNS yang asli telah dijadikan jaminan di PT. BPD Bali. Dalam hal ini, berarti 1 orang nasabah atau debitor telah menggunakan 1 agunan dalam 2 Bank yang berbeda. Hal tersebut diatas dapat menimbulkan permasalahan dalam ilmu hukum berupa klasifikasi hukum jaminan dalam penggunaan fotokopi SK Pengangkatan PNS yang dilegalisasi sebagai jaminan pada Perjanjian Kredit Bank.

Begitu banyaknya Bank Perkreditan Rakyat (selanjutnya disebut BPR) yang berkembang dan bersaing di Provinsi Bali membuat salah satu Pihak BPR menerapkan kebijakan tersebut diatas. PT. Bank Perkreditan Rakyat Ashi (selanjutnya disebut PT. BPR. Ashi) terletak di Jalan Raya Sempidi No.8 Kabupaten Badung ProvinsiBalitelahmemberikan kebijakan kredit kepada para pegawai negeri sipil yang sudah memiliki kredit di PT. BPD Bali dengan menggunakan agunan berupa SK Pengangkatan PNS, dapat kembali mengajukan kredit di PT. BPR Ashi dengan menggunakan fotokopi SK Pengangkatan PNS yang dilegalisasi sebagai agunan. Dalam hal ini pihak Bank memasukan agunan tersebut ke dalam fiducie eigendom 
overdract $(\mathrm{FEO})^{6}$ dalam bentuk perjanjian dibawah tangan yang hanya diwarmeking oleh pihak Notaris. Kredit semacam ini di PT BPR Ashi disebut dengan Kredit Program. ${ }^{7}$

Pentingnya asas kebebasan berkontrak dalam kesepakatan perjanjian kredit bank dan asas kepercayaan oleh pihak Bank kepada debitor merupakan kunci dari berjalannya perjanjian kredit tersebut. Apabila pihak debitor telah melakukan wanprestasi dalam pemenuhan kewajibannya kepada pihak Bank, pihak Bank belum memikirkan mengenai akibat hukum yang ditimbulkan dan ganti rugi dalam penggunaan agunan berupa Fotokopi SK Pengangkatan PNS yang dilegalisasi agar dapat mengembalikan kerugian yang ditimbulkan oleh pihak Debitor kepada pihak Bank selaku Kreditor.

Oleh karena itu, penting bagi pihak PT. BPR Ashi untuk mengetahui akibat hukum dan implikasi yuridis dalam perjanjian kredit Bank yang menggunakan agunan berupa Fotokopi SKPengangkatanPNSyangdilegalisasi

6 Fiducie eigendom overdract (FEO), yaitu penyerahan hak milik berdasarkan atas kepercavaan. Dikutip dari Salim HS, Perkembangan Hukum Jaminan di Indonesia,(Jakarta: PT Raja Grafindo Persada, 2004), hlm. 55.

7 Termuat dalam Pedoman Kredit PT BPR Ashi, BAB II Kebijakan Perkreditan Bank, Kredit ini merupakan Kredit Program, yaitu kredit yang diberikan kepada nasabah, pegawai, baik pegawai negeri maupun pegawai swasta yang dilakukan secara kolektif, dan pembayaran kreditnya juga dilakukan secara berkelompok melalui pemotongan gajih dari bendahara pada instansi tersebut, dengan mengangsur pokok dan atau bunga setiap bulannya, hlm. 18 agar ke depan pihak Bank lebih cermat dalam mengeluarkan kebijakan dana kredit. Berdasarkan latar belakang masalah yang telah dikemukakan tersebut diatas maka penulis membuat karya ilmiah dengan judul: "Implikasi Yuridis Fotokopi Surat Keputusan Pengangkatan Pegawai Negeri Sipil yang dilegalisasi Sebagai Agunan dalam Perjanjian Kredit Bank (Studi di PT Bank Perkreditan Rakyat Ashi Kabupaten Badung Provinsi Bali)".

Berdasarkan latar belakang permasalahan tersebut diatas, maka dapat dirumuskan permasalahan yang terjadi dalam pokok kajian adalah sebagai berikut:

1. Apakah yang menjadi landasan yuridis pihak Bank menerima fotokopi SK Pengangkatan PNS yang dilegalisasi digunakan sebagai agunan dalam perjanjian kredit?

1) Bagaimanakah implikasi yuridis terhadap fotokopi SK Pengangkatan PNS yang dilegalisasi sebagai agunan dalam perjanjian kredit?

Originalitas penelitian dilakukan dengan membandingkan beberapa penelitian, diantaranya:

1. Pelaksanaan Perjanjian Kredit dengan Jaminan Surat Keputusan Pengangkatan Pegawai Negeri Sipil(StudiPenelitiandiPT.Bank Rakyat Indonesia (Persero) Tbk, Cabang Lumajang) yang ditulis oleh Rahmadi Halim pada jurnal Hukum Program Pascasarjana 
Universitas Diponegoro. Dalam penelitian tersebut membahas tentang prosedur pencairan kredit dengan menggunakan jaminan Surat Keputusan Pengangkatan Pegawai Negeri Sipil. ${ }^{8}$ Sedangkan penelitian ini membahasmengenaipenggunaan fotokopi Surat Keputusan Pengangkatan Pegawai Negeri Sipil yang dilegalisasi sebagai agunan kredit.

2. Pelaksanaan Perjanjian Kredit dengan Jaminan Surat Keputusan Pengangkatan Pegawai Negeri Sipil di PT. Bank Rakyat Indonesia (Persero) Cabang Salatiga yang ditulis oleh Fitria Dewi Purnamasari pada jurnal Hukum Program Pascasarjana Universitas Diponegoro. Dalam penelitian tersebut lebih membahas pada klausula yang dicantumkan dalam perjanjian kredit. ${ }^{9}$ Sedangkan dalam penelitian ini membahas tentang implikasi yuridis dalam penggunaan fotokopi Surat Pengangkatan Pegawai Negeri Sipil yang dilegalisasi sebagai agunan.

8 Rahmadi Halim, Pelaksanaan Perjanjian Kredit dengan Jaminan Surat Keputusan Pengangkatan Pegawai Negeri Sipil (Studi Penelitian di PT. Bank Rakyat Indonesia (Persero) Tbk, Cabang Lumajang), 2006, Tesis Universitras Diponegoro.

9 Fitria Dewi Purnamasari, Pelaksanaan Perjanjian Kredit dengan Jaminan Surat Keputusan Pengangkatan Pegawai Negeri Sipil di PT. Bank Rakyat Indonesia (Persero) Cabang Salatiga, 2007, Tesis Universitas Diponegoro.
Penelitian hukum ini mempunyai 2 (dua) tujuan yakni Tujuan Umum dan Tujuan Khusus:

1) Tujuan Umum: untuk mengetahui secara mendalam mengenai implikasi yuridis penggunaan agunan berupa Fotokopi SK Pengangkatan PNS yang dilegalisasi dalam perjanjian kredit Bank, sehingga dapat memberi sumbangan pemikiran mengenai aspek hukum dan akibat hukum bagi pihak Bank selaku kreditor dan pihak nasabah selaku debitor dalam perjanjian kredit Bank tersebut.

2) Tujuan Khusus: Untuk mendeskripsikan landasan yuridis pihak Bank dalam penggunaan agunan berupa fotokopi SK Pengangkatan PNS yang dilegalisasi dalam perjanjian kredit Bank. Untuk menganalisis tentang implikasi yuridis dan klasifikasi hukum jaminan terhadap fotokopi SK Pengangkatan PNS yang dilegalisasi digunakan sebagai agunan dalam perjanjian kredit Bank.

\section{Metode Penelitian}

Pendekatan penelitian adalah metode atau cara mengadakan penelitian. ${ }^{10}$ Jenis penelitian yang saya gunakan dalam penelitian ini adalah penelitian hukum empiris yakni

10 Suharsimi Arikunto, Prosedur Penelitian (Suatu Pendekatan Praktek), (Jakarta: Rieneka Cipta, 2002), hlm. 23. 
penelitian hukum yang objek kajiannya meliputi ketentuan dan mengenai pemberlakuan atau implementasi ketentuan hukum normatif (kodifikasi, Undang-Undang) secara in action / in abstracto pada setiap peristiwa hukum yang terjadi dalam masyarakat in concreto. ${ }^{11}$

Penelitian hukum empiris ini dilakukan untuk memastikan apakah hasil dari penerapan pada peristiwa hukum in concreto tersebut telah sesuai atau tidak dengan ketentuan Undang-Undang atau perjanjian telah dilaksanakan sebagaimana mestinya atau tidak, sehingga para pihak yang berkepentingan mencapai tujuannya. Penelitian hukum empiris harus dilakukan di lapangan dengan metode dan teknik penelitian lapangan dengan cara melihat dan meneliti fakta-fakta yang terjadi di lapangan tentang penggunaan Fotokopi SK Pengangkatan PNS yang dilegalisasi sebagai agunan dalam perjanjian kredit Bank menurut klasifikasi Hukum Jaminan dalam Undang-Undang.

Pendekatan-pendekatan yang digunakan di dalam penelitian hukum ini adalah pendekatan kasus (case approach) dan pendekatan konseptual (conceptual approach) ${ }^{12}$ untuk menghasilkan konsep perbaikan, perjanjian kredit, pendapat ahli dari literatur, jurnal, Koran, dan artikel dari

11 Abdulkadir Muhammad, Hukum dan Penelitian Hukum, (Bandung: Citra Aditya Bakti, 2004), hlm. 134.

12 Peter Mahmud Marzuki, Penelitian Hukum,(Jakarta: Prenada Media Group, 2009), hlm. 93. internetsebagaibahanpendekatanuntuk menganalisa. ${ }^{13}$ Penelitian ini bersifat preskriptif ${ }^{14}$ analitis ${ }^{15}$ yang diharapkan dapat menghasilkan argumentasi dan konsep sebagai preskripsi yang sudah mengandung nilai dan dapat menjadi salah satu pertimbangan dalam menyelesaikan permasalahan yang berhubungan dengan penelitian ini. Dalam klasifikasi ini agar dapat ditujukan untuk menggambarkan secara tepat mengenai situasi atau kejadian dan menerangkan hubungan antara kejadian tersebut dengan masalah yang akan diteliti, karena dari hasil penelitian ini diharapkan dapat memberikan analisis dan pembenaran mengenai penggunaan agunan yang benar dan seharusnya digunakan dalam perjanjian kredit Bank.

Penelitian ini merupakan penelitian hukum empiris yang menggunakan bahan hukum terdiri dari 2 (dua) bahan hukum yaitu:

13 Metode penelitian dengan pendekatan perbandingan disebut comparative approach yaitu membandingkan pendapat ahli untuk melihat suatu masalah

14 Ilmu hukum yang preskriptif merupakan ilmu yang mempelajari tujuan hukum, nilai-nilai keadilan, validitas aturan hukum, konsep-konsep hukum dan norma hukum. Dikutip dari Peter Mahmud Marzuki, Penelitian Hukum, (Jakarta: Kencana, 2005), hlm. 22.

15 Jika pada klasifikasi diatas variabel dijelaskan dan diuji, maka pada klasifikasi "analitis" ini, masing-masing variabel dihubungkan yang pada dasarnya dikembalikan pada tiga aspek, yaitu : mengklasifikasi, membandingkan dan menghubungkan.Dikutip dari Jujun $\mathrm{S}$ Suriasumantri, Ilmu Dalam Perspektif Moral, Sosial dan Politik : Sebuah Dialog tentang Keilmuan Dewasa Ini, (Jakarta: Gramedia, 1986), hlm. 61-62. 
Bahan Hukum Primer (data lapangan), yakni bahan hukum yang diperoleh oleh peneliti dari sumber asalnya yang pertama dan belum diolah dan diuraikan oleh orang lain. Data yang diperoleh didapatkan secara langsung melalui teknik analisa data proposal nasabah, wawancara dengan informan di PT.BPR Ashidi Kabupaten Badung Provinsi Bali dan data yang didapat melalui perjanjian kredit Bank terkait. Adapun bahan sumber hukum tersebut terdiri dari: Akta Pendirian PT, System Operational Procedure (SOP), Proposal debitor, dan Akad perjanjian kredit bank.

Bahan hukum sekunder dalam penelitian hukum empiris merupakan bahan yang diperoleh dari kepustakaan yaitu dengan meneliti bahan-bahan hukum yang terdiri dari :KUH Perdata; Undang-Undang Republik Indonesia Nomor 10 Tahun 1998 tentang Perubahan Atas UndangUndang Nomor 7 Tahun 1992 Tentang Perbankan; Undang-Undang Nomor 42 Tahun 1999 tentang Jaminan Fidusia; Undang-Undang Nomor 40 Tahun 2007 tentang Perseroan Terbatas; Undang-Undang Nomor 43 Tahun 1999 tentang Perubahan atas UndangUndang Nomor 8 Tahun 1974 tentang Pokok-Pokok Kepegawaian; Surat Keputusan Direksi Bank Indonesia No. 23/69/KEP/DIR tanggal 28 Februari 1991; beserta literatur-literatur hukum, jurnal hukum, majalah, karya tulis, dan hasil penelitian yang ada kaitannya dengan permasalahan dalam penelitian ini.
Penelitian ini dilakukan dengan metode pengumpulan data-data di lapangan tempat meneliti beserta bahan hukum, melalui studi kepustakaan, wawancara dan studi dokumentasi. Metode penelusuran bahan hukum ini dilakukan dalam bentuk kajian terhadap meneliti langsung di lapangan atau ditempat meneliti, literatur, dokumen-dokumen, karya ilmiah dan berita pada internet.

Guna mendapatkan hasil atau jawaban atas permasalahan yang diteliti, maka keseluruhan data yang terkumpul selanjutnya diolah dan dianalisis dari aspek praktek dan teorinya. Analisa data yang telah dilakukan adalah analisa kualitatif, dalam arti keseluruhan data yang terkumpulkan diklasifikasikan sedemikian rupa kemudian diambil yang ada hubungannya dengan permasalahan yang akan dibahas. Akhirnya akan diperoleh kesimpulan untuk menjawab semua permasalahan yangdicantumkan. Setelahdatatersebut semua diolah, selanjutnya pembahasan disajikan secara analisis deskriptif yaitu memaparkan secara lengkap dan mendetail aspek-aspek tertentu yang berkaitan atau bersangkutan dengan masalah, diberikan uraian dan disajikan secara berurutan sesuai dengan data yang pada akhirnya menjadi sebuah tesis. 
III. HASIL DAN PEMBAHASAN

3.1 Landasan Yuridis Pihak Bank Menerima Fotokopi SK Pengangkatan PNS yang dilegalisasi sebagai Agunan dalam Perjanjian Kredit

Prinsip kehati-hatian pihak Bank dalam mengeluarkan dana kredit merupakan pelaksanaan dasar analisis kredit. Menurut Pasal 8 UU Perbankan, dalam melaksanakan kegiatan usahanya yang berupa pemberian kredit bank antara lain: ${ }^{16}$

1) Wajib mempunyai keyakinan berdasarkan analisis yang mendalam atas itikad dan kemampuan serta kesanggupan debitor untuk melunasi utangnya sesuai dengan yang diperjanjikan (Pasal 8 ayat (1));

2) Memiliki dan menerapkan pedoman perkreditan sesuai dengan ketentuan yang ditetapkan oleh Bank Indonesia (Pasal 8 ayat (2)).

Mengenai analisis kredit pihak bank telah tercantum dalam Pasal 8 ayat (1) UU Perbankan yang dapat dijelaskan berdasarkan ketentuan tersebut yaitu : Pertama, dalam memperoleh keyakinan tersebut, sebelum memberikan dana kredit, bank harus melakukan penilaian secara teliti dan seksama atas kepribadian, kemampuan, modal, agunan, dan prospek usaha calon debitor; Kedua, sebagaimanabahwaagunanmerupakan

16 M.Bahsan, Hukum Jaminan dan Jaminan Kredit Perbankan Indonesia, (Jakarta: PT Rajagrafindo Persada), 2007, hlm. 79. salah satu unsur pemberian kredit, maka apabila berdasarkan unsur-unsur lain telah dapat diperoleh keyakinan atas kemampuan debutir dalam pengembalian hutangnya, agunan dimaksud hanya dapat berupa barang dan hak tagih yang dibiayai dengan kredit yang bersangkutan.

Dalam penelitian ini, tentunya pihak PT BPR Ashi telah menerapkan prinsip kehati-hatian tersebut dalam analisis kredit sebelum penyaluran dana kreditnya. Analisis kredit berdasarkan prinsip kehati-hatian telah dijalankan pihak PT BPR Ashi dengan menggunakan Prinsip 5C. Seorang account officer dalam melakukan analisis terhadap suatu permohonan kredit harus berpegang teguh pada 5C prinsip analisis kredit, yaitu: ${ }^{17}$

Character: penilaian terhadap watak atau kepribadian calon debitor, dengan tujuan untuk memperoleh kepastian bahwa pinjaman / debitor akan bersedia memenuhi janji atau kewajibannya membayar kembali kredit yang telah diterima sesuai dengan perjanjian yang telah dibuat.

Capacity: penilaian terhadap kemampuan debitor untuk melakukan pembayaran kembali kreditnya. Kemampuan ini diukur dengan catatan prestasi debitor di masa lalu (track record), apabila debitor pernah pinjam kepada pihak manapun, dan atau pihak bank lain, yang didukung dengan analisis administrative maupun

17 Pedoman Kebijaksanaan Perkreditan Bank PT BPR ASHI, Struktur Organisasi Kredit, hlm. 36. 
pengamatan langsung di lapangan terhadap kegiatan usaha maupun tempat mencari nafkah.

Capital: penilaian terhadap modal yang dimiliki oleh calon debitor. Kemampuan ini diukur dengan membandingkan jumlah modal sendiri terhadap keseluruhan modal yang diperlukan untuk menjalankan usaha (kredit yang diperlukan untuk modal usaha).

Collateral:jaminanyang dimiliki calon debitor atau kekayaan yang dimilikicalon debitor untuk mengkover kredit yang akan diterimanya yang memiliki nilai marketable dan layak untuk dijaminkan sebagai agunan, baik asset tak bergerak (tanah) maupun barang bergerak (kendaraan) dan lainlain.

Conditions: bank harus melihat kondisi ekonomi secara umum (makro) dan secara spesifik melihat keterkaitannya dengan jenis usaha calon debitor. Hal ini dilakukan karena keadaan eksternal perusahaan mempunyai peranan yang sangat besar dalam memperlancar atau timbulnya resiko atas usaha yang dibiayai (untuk kredit yang dipergunakan untuk kegiatan usaha). Sedangkan untuk kredit yang dipergunakan untuk konsumtif harus dikaitkan dengan situasi kondisi ekonomi yang disebabkan oleh kebijaksanaan pemerintah. ${ }^{18}$

18 Pedoman Kebijaksanaan Perkreditan Bank PT BPR ASHI, Struktur Organisasi Kredit, hlm. 36-37.
Sebelum kredit dicairkan, account officer ${ }^{19}$ (petugas kredit) harus melakukan analisis kredit atau pendekatan secara cermat dan teliti berdasarkan prinsip 5C tersebut diatas dan menggunakan pendekatan analisis sebagai berikut: 1) pendekatan kemampuan pembayaran (Repayment capacity approach); 2) pendekatan karakter (Character Approach); 3) pendekatan kelayakan usaha (fesibility approach).

Adapun syarat-syarat dan langkah debitor dalam pengajuan kredit di PT BPR Ashi yang berdasarkan atas prinsip kehati-hatian bank, yaitu:

a) Mengisi formulir permohonan kredit sesuai dengan jenis kredit.

b) Mengisi fotokopi identitas diri KTP / SIM, Surat Keterangan Domisili Suami dan Istri.

c) Menyampaikan laporan keuangan perusahaan minimal 3 bulan terakhir.

d) Menyampaikan bukti penghasilan dan atau surat keterangan (petikan daftar/slip gaji) untuk kredityang bersumber dari pendapatan tetap.

e) Melengkapi bukti rekening bank baik rekening kredit maupun tabungan bank lain 6 bulan terakhir.

f) Menyerahkan jaminan bukti kepemilikan kendaraan bermotor (BPKB) kendaraan (asli) dan

19 Tugas account officer di PT BPR ASHI tercantum dalam Pedoman Kebijaksanaan Perkreditan Bank PT BPR ASHI, Struktur Organisasi Kredit, hlm. 26-28. 
atau Sertifikat Hak Milik jaminan tanah atau bangunan (SHM/HGB).

g) Fotokopi identitas pemilik jaminan suami istri untuk barang tidak bergerak.

h) BPKB kendaraan fotokopi STNK yang berlaku dan kwitansi kosong 3 lembar bermaterai cukup yang di tandatangani atas nama BPKB, kwitansi jual beli dan apabila atas nama orang lain, dilampiri surat pernyataan kepemilikan bahwa kendaraan belum dibalik nama dan surat kuasa menjaminkan.

i) Kendaraan yang dipakai jaminan adalah jenis dan merk kendaraan yang memiliki purna jual yang baik.

j) SK Pengangkatan, Karip, SK terakhir dan petikan gaji terakhir untuk kredit kepada pegawai negeri maupun instansi swasta.

k) Bilyet deposito atau buku tabungan yang ada kalau kredit dengan jaminan cast collateral. ${ }^{20}$

Dari semua langkah-langkah yang dilakukan oleh pihak bank, sangat jelas pihak bank menjalankan kegiatan usahanya berdasarkan prinsip kehati-hatian yang tercantum dalam Pedoman Kebijaksanaan Perkreditan PT BPR Ashi. Dalam penggunaan fotokopi SK Pengangkatan PNS yang dilegalisasi, petugas kredit terlebih dahulu melakukan analisis terhadap

20 Pedoman Kebijaksanaan Perkreditan Bank PT BPR ASHI, Struktur Organisasi Kredit, hlm. 32-33. calon debitor tentang kesanggupan calon debitor dalam pemenuhan membayar kembali kredit tersebut. Kepercayaan merupakan faktor utama yang menjadi prinsip dalam proses kredit tersebut hingga dana kredit tersebut dicairkan. ${ }^{21}$

\subsubsection{Pertanggung jawaban Para Pihak dalam Penggunaan Fotokopi SK Pengangkatan PNS yang dilegalisasi sebagai Agunan}

Pada umumya, para pihak dalam perjanjian kredit akan memiliki kewajiban masing-masing setelah perjanjian kredit tersebut disepakati dan ditandatangani oleh masingmasing pihak. Kewajiban pihak bank selaku kreditor dalam perjanjian kredit program adalah sebagai berikut:

1) Memutuskan batas maksimum pemberian kredit pada pihak terkait.

2) Menentukan syarat-syarat terkait perjanjian kredit para pihak.

3) Menentukan atau penilaian jaminan yang diberikan debitor.

4) Melaksanakan pencairan kredit kepada debitor yang telah mendapat persetujuan oleh pihak Credit Committee ${ }^{22}$.

21 Hasil wawancara dengan Kepala Bagian Kredit PT BPR Ashi pada hari selasa, tanggal 2 Mei 2017.

22 Credit committee merupakan struktur organisasi perkreditan di PT BPR Ashi yang berfungsi sebagai lembaga yang berwenang didalam mengambil keputusan tentang persetujuan dan atau penolakan atas permohonan kredit, perpanjangan kredit serta keputusan tentang tingkat kolektibilitas kredit, penanganan kredit bermasalah, dan bahkan sampai dengan penghapus bukuan kredit. 
5) Menyimpan data terkait agunan, surat kuasa dan perjanjian kredit tersebut.

Kewajiban pihak nasabah atau debitor dalam perjanjian kredit program ini adalah sebagai berikut:

1) Bertanggung jawab sepenuhnya mengenai keaslian dankebenaran atas seluruh data diri debitor dana data kelengkapan administrasi yang termasuk dalam syarat permohonan kredit.

2) Bertanggung jawab sepenuhnya atas kelancaran pembayaran atau angsuran kredit program setiap bulannya sampai kredit tersebut dinyatakan lunas oleh pihak bank.

Pihak debitor memberitahu pihak kreditor dan memberikan hak substitusi kepada bendahara gaji dinas atau instansi kepegawaian yang ditunjuk untuk melakukan pembayaran angsuran kredit.

Perjanjian kredit bank akan termuat klausula-klausula yang sebagian besar merupakan upaya untuk melindungi pihak kreditor dalam penyaluran dana kredit tersebut. Klausula merupakan serangkaian persyaratan yang diformulasikan dalam upaya pemberian kredit ditinjau dari aspek finansial dan hukum.

Yang beranggotakan antara lain: Komisaris, Direktur Utama, Direktur, Kepala Bagiuan Marketing dan Pemasaran, Kepala Bagian Operasional dan Treasury, Kredit Support, Account Officer, termuat dalam Pedoman Kebijaksanaan Perkreditan Bank PT BPR ASHI, Struktur Organisasi Kredit, hlm. 2021.
Berdasarkan atas klausula yang termuat mengenai aspek finansial dan hukum dalamperjanjiankreditbank, dipastikan dalam hal ini bahwa Pegawai Negeri Sipil bertanggungjawab atas perbuatan hukum dalam perjanjian kredit yang dibuatnya, kewajiban ini tentu sudah melekat sejak Pegawai Negeri Sipil menyetujui dan menandatangani perjanjian kredit yang diberikan oleh pihak bank dalam hal ini pihak PT BPR Ashi.

\subsection{Implikasi Yuridis terhadap Fotokopi SK Pengangkatan PNS yang dilegalisasi sebagai Agunan dalam Perjanjian Kredit}

Pengertian mengenai agunan telah dinyatakan dalam Pasal 1 angka 23 UU Perbankan bahwa agunan adalah "Jaminan tambahan yang diserahkan Nasabah Debitor kepada bank dalam rangka pemberian fasilitas kredit atau pembiayaan berdasarkan prinsip syariah". Tujuan agunan adalah untuk mendapatkan fasilitas dan/atau pembiayaan dari bank, yang diserahkan oleh debitor kepada pihak bank atau kreditor. Dapat dikatakan bahwa agunan tersebut merupakan suatu benda yang diserahkan oleh debitor kepada kreditor untuk meyakinkan kreditor bahwa pinjaman tersebut akan dilunasi debitor.

Pengertian benda dalam hukum dinyatakan dalam Pasal 499 KUHPerdata yang berbunyi "Menurut paham Undang-Undang 
yang dinamakan kebendaan adalah tiap-tiap barang dan tiap-tiap hak yang dapat dikuasai oleh hak milik". Benda dalam pandangan hukum perdata merupakan segala sesuatu yang dapat diberikan dan/atau diletakkan suatu hak di atasnya, terutama yang berupa hak milik. Dengan demikian, yang dapat memiliki sesuatu hak tersebut merupakan subyek hukum, sedangkan sesuatu yang dibebankan hak adalah obyek hukum. ${ }^{23}$ Selanjutnya, benda tersebut bukanlah segala benda yang berwujud dan dapat diraba oleh panca indera saja, melainkan termasuk juga pengertian benda yang tidak berwujud, seperti misalnya kekayaan seseorang (memiliki nilai ekonomis dalam penggunaan jaminan). Istilah benda yang dipakai untuk pengertian kekayaan, termasuk di dalamnya tagihan atau piutang dan hak-hak lainnya, misalnya tabungan, bunga atas deposito, termasuk juga SK Pengangkatan PNS.

Agunan yang dijadikan salah satu persyaratan dalam pemberian kredit yaitu agunan berupa benda yang menurut hukum digolongkan sebagai barang tidak bergerak seperti tanah dan bangunan sedangkan berupa benda yang menurut hukum digolongkan sebagai barang bergerak seperti kendaraan bermotor yang dilengkapi dengan surat-surat bukti kepemilikan kendaraan bermotor, agunan berupa surat-surat berharga maupun surat-

23 Soebekti, Pokok-pokok hokum perdata. (Jakarta: Internusa, 2001), hlm. 60 surat yang berharga yang di dalamnya melekat hak tagih, seperti saham, efek, surat keputusan, pengangkatan pegawai negeri sipil (SK Pengangkatan PNS ${ }^{24}$ atau berupa surat keputusan pensiun pegawai negeri sipil, dan lain sebagainya. Walaupun SK Pengangkatan PNS bukan merupakan benda yang dapat dipindahtangankan (yang mempunyai nilai pengalihan), tetapi perkembangan dalam praktik perbankan yang melihat sisi ekonomis pada surat tersebut menjadikannya dapat diterima oleh beberapa bank sebagai jaminan kredit.

Apabila dikaitkan dengan hukum benda mengenai penggunaan fotokopi SK Pengangkatan PNS yang dilegalisasi sebagai agunan dalam perjanjian kredit di PT BPR Ashi, fotokopi SK Pengangkatan PNS yang dilegalisasi memiliki unsur-unsur benda yang dapat dijadikan agunan, yaitu sebagai berikut:

1) Merupakan benda tidak berwujud karena fotokopi SK Pengangkatan PNS yang dilegalisasi berisikan hak-hak yang dimiliki oleh PNS (debitor). Hak-hak tersebut memiliki nilai ekonomis karena dalam SK Pengangkatan PNS disertakan petikan gaji seorang PNS tersebut yang dapat dijadikan bahan

24 Ajib Rakhmawanto, Seleksi Pengangkatan Pegawai Negeri Sipil Dalam Jabatan Struktural, Jurnal Kebijakan Dan Manajemen PNS Volume 1 Tahun 2007, (Jakarta: Pusat Pengkajian Dan Penelitian Kepegawaian BKN, 2010), hlm. 2 
pertimbangan oleh pihak bank dalam pemenuhan kewajiban PNS (debitor) guna pelunasan kredit.

2) Merupakan benda bergerak karena SK Pengangkatan PNS yang dilegalisasi dapat dipindahkan secara nyata sebagaimana telah tercantum dalam Pasal 509-511 KUHPerdata.

3) Merupakan benda sudah ada karena dalam perjanjian kredit bank didahulukan benda yang sudah ada atau telah dimiliki debitor digunakan sebagai agunan dalam perjanjian kredit bank.

4) Merupakanbendaterdaftarkarena fotokopi SK Pengangkatan PNS merupakan Surat Keputusan yang diberikan oleh pejabat instansi dalam negeri terkait dan tentunya telah didaftarkan di instansi tersebut.

Hal tersebut diatas menjadi dasar pertimbangan pihak bank bahwa fotokopi SK Pengangkatan PNS yang dilegalisasi dapat dijadikan agunan dalam perjanjian kredit bank di PT BPR Ashi.

Penggunaan fotokopi SK Pengangkatan PNS yang dilegalisasi sebagai agunan dalam klasifikasi hukum jaminan dapat diuraikan sebagai berikut:

1) Termasuk ke dalam jaminan yang lahir karena perjanjian. Fotokopi SK Pengangkatan PNS yang dilegalisasi dalam perjanjian kredit ini merupakan jaminan yang ada karena diperjanjikan terlebih dahulu oleh kedua pihak.

2) Termasuk ke dalam penggolongan jaminan khusus. Fotokopi SK Pengangkatan PNS yang dilegalisasi merupakan jaminan yang bersifat kebendaan atau perorangan. Tergolong jaminan khusus karena bertujuan agar kreditor memiliki hak utama atas benda jaminan yang diberikan oleh debitor dan perikatannya dilakukan secara khusus.

3) Termasuk ke dalam jaminan yang bersifat kebendaan. Sudah dijelaskan dalam hukum benda mengenai agunan berupa fotokopi SK Pengangkatan PNS yang dilegalisasi termasuk ke dalam benda yang dapat digunakan sebagai jaminan.

4) Termasuk ke dalam jaminan yang memiliki objek benda bergerak. Dikatakan benda bergerak karena fotokopi SK Pengangkatan PNS yang dilegalisasi digunakan sebagai agunan dapat dipindahkan secara nyata.

Pihak Bank dalam hal ini PT BPR Ashi memberikan kredit dengan agunan berupa fotokopi SK Pengangkatan PNS yang dilegalisasi, percaya bahwa jaminan tersebut sudah cukup menggambarkan kemampuan 
nasabah dalam melaksanakan pemenuhan kewajiban atau pelunasan kredit yang diberikan. Kepercayaan pihak bank atas pelunasan kredit debitor atas dasar SK Pengangkatan PNS yang diikutkan dengan petikan slip gaji debitor dan surat kuasa debitor kepada pihak bank untuk menarik gaji debitor dari bendahara instansi terkait sesuai dengan kesepakatan schedule pembayaran debitor. Dapat dikatakan bahwa SK Pengangkatan PNS memiliki nilai ekonomis bagi Pegawai Negeri Sipil (debitor) karena terdapat petikan gajih yang ikut serta dalam diberikannya SK Pengangkatan PNS tersebut. Dalam kata lain, pihak Bank berani menerima fotokopi SK Pengangkatan PNS sebagai agunan dalam perjanjian kredit karena telah dilegalisasi oleh pihak instansi terkait. $^{25}$

\section{KESIMPULAN}

1. Landasan yuridis pihak bank dalam menyalurkan kredit program yaitu dengan Analisis kredit berdasarkan prinsip kehati-hatian telah dijalankan pihak PT BPR Ashi dengan menggunakan Prinsip 5C, yaitu : Character, Capacity, Capital, Collateral, Conditions dan 3 (tiga) prinsip lain, yaitu: pendekatan kemampuan pembayaran (Repayment capacity approach), pendekatan karakter (Character Approach),

25 Hasil wawancara dengan Direktur PT BPR Ashi pada hari selasa, tanggal 2 Mei 2017. pendekatan kelayakan usaha (fesibility approach). Hal-hal yang berkaitan dengan identitas debitor, jangka waktu, jaminan, wanprestasi dan batas pinjaman sebesar Rp. 25.000.000,dicantumkan dalam perumusan perjanjian kredit bank atau akad kredit yang disepakati dan dibubuhkan tandatangan kedua belah pihak.

2. Implikasi Yuridis fotokopi SK Pengangkatan PNS yang dilegalisasi sebagai agunan kredit merupakan Analisis karakter dari seorang debitor yaitu penerapan prinsip mengenal nasabah (know your customer principles) sesuai dengan Peraturan Bank Indonesia Nomor 3/10/PBI/2001 tentang Penerapan Prinsip Mengenal Nasabah yang lebih menekankan unsur kepercayaan pada karakter daripada seorang PNS yang selalu menjaga dan tidak merusak kredibilitasnya. Ketentuan mengenai klasifikasi hukum benda dan hukum jaminan terhadap fotokopi SK Pengangkatan PNS yang dilegalisasi tidak dapat dijadikan sebagai jaminan utama dalam perjanjian kredit bank tetapi hanya sebagai syarat tambahan.

\section{DAFTAR PUSTAKA \\ Buku}

Abdulkadir Muhammad, 2004, Hukum dan Penelitian Hukum, Citra Aditya Bakti, Bandung. 
Ajib Rakhmawanto, 2010,Seleksi Pengangkatan Pegawai Negeri Sipil Dalam Jabatan Struktural, Pusat Pengkajian Dan Penelitian Kepegawaian BKN, Jakarta.

H.R. Daeng Naja, 2005, Hukum Kredit dan Bank Garansi,PT. Citra AdityaBakti, Bandung.

Hermansyah, 2005,Hukum Perbankan Nasional Indonesia, Kencana, Jakarta.

Jujun S Suriasumantri, 1986, Ilmu Dalam Perspektif Moral, Sosial dan Politik : Sebuah Dialog tentang Keilmuan Dewasa Ini, Gramedia, Jakarta.

M.Bahsan, 2007Hukum Jaminan dan Jaminan Kredit Perbankan Indonesia,PT Rajagrafindo Persada, Jakarta.

Peter Mahmud Marzuki, 2005, Penelitian Hukum, Kencana, Jakarta.

Peter Mahmud Marzuki, 2009, Penelitian Hukum, Prenada Media Group, Jakarta.

Salim HS, 2004,Perkembangan Hukum Jaminan di Indonesia, PT Raja Grafindo Persada, Jakarta.

Soebekti, 2001,Pokok-pokok hokum perdata, Internusa, Jakarta.

Suharsimi Arikunto, 2002,Prosedur Penelitian (Suatu Pendekatan Praktek),Rieneka Cipta, Jakarta. Rahmadi Halim, 2006, Pelaksanaan Perjanjian Kredit dengan Jaminan Surat Keputusan Pengangkatan Pegawai Negeri Sipil (Studi Penelitian di PT. Bank Rakyat Indonesia (Persero)
Tbk, Cabang Lumajang), Tesis, Program Studi Kenotariatan, Univ. Diponegoro, Semarang

Fitria Dewi Purnamasari, 2007, Pelaksanaan Perjanjian Kredit denganJaminan SuratKeputusan Pengangkatan Pegawai Negeri Sipil di PT. Bank Rakyat Indonesia (Persero) Cabang Salatiga, Tesis, Program Studi Kenotariatan, Univ. Diponegoro, Semarang

\section{Peraturan Perundang-undangan}

Kitab Undang - Undang Hukum Perdata

Undang-Undang Republik Indonesia Nomor 10 Tahun 1998 tentang Perubahan Atas Undang-Undang Nomor 7 Tahun 1992 Tentang Perbankan. Lembaran Negara Republik Indonesia Tahun 1998 Nomor 182, Tambahan Lembaran Negara Republik Indonesia Nomor 3790.

Undang-Undang Nomor 42 Tahun 1999 tentang Jaminan Fidusia;

Undang-Undang Nomor40 Tahun 2007 tentang Perseroan Terbatas;

Undang-Undang Nomor 43 Tahun 1999 tentang Perubahan atas Undang-Undang Nomor 8 Tahun 1974 tentang Pokok-Pokok Kepegawaian. Lembaran Negara Republik Indonesia Tahun 1999 Nomor 169.

Surat Keputusan Direksi Bank Indonesia No. 23/69/KEP/DIR tanggal 28 Februari 1991 